\title{
Studying the Interrelationships between the various Impediments to Green Media Selection in India
}

\author{
Bhoomica Aggarwal \\ HCL Technologies Private \\ Limited \\ Noida, India
}

\author{
Remica Aggarwal \\ School of Business, \\ University of Petroleum \& \\ Energy Studies \\ Dehradun, India
}

\author{
Anu Aggarwal \\ NAWADCO \\ Delhi, India
}

\author{
S. P. Singh \\ Department of \\ Management Studies \\ IIT Delhi, Delhi, India
}

\begin{abstract}
Environmental marketing or green marketing or ecological marketing placed emphasis on sustainability of marketing activities of a firm and sustainable consumption of a consumer so that these create either a positive impact or lessen the negative impact on the environment. However, adopting green marketing is not easy as it involves a whole gamut of activities ranging from developing innovative or renovating existing products as per environment's ecological standards, changes to the production process, a modified form of advertising as well as packaging changes. Consequently, manufacturers as well as marketers faces various barriers or impediments while adopting green marketing and selection of green media for advertising. This paper aims to identify various impediments or barriers towards the adoption of green marketing in Indian context and to measure the interrelationships amongst the identified factors using Interpretive Structural Modelling (ISM) technique.
\end{abstract}

\section{Keywords}

Interpretive Structural Modeling Methodology (ISM); Green marketing ; Ecological Marketing

\section{INTRODUCTION}

Now days, environment friendly goods and services are becoming popular. Such green lifestyles portrayed by consumers as well as by manufacturers and marketers could be personal choices or could be borne by them due to pressure from their employer organization or from regulatory government bodies but overall it helps in ensuring sustainable consumption of resources at a society level. In India, though the products are becoming popular among masses but still it is in nascent stage and has a long way to go .

Like consumers are increasingly adopting the green products, the marketers also need to adopt a better marketing mix for their products in order to change consumers' negative perception towards green products. As we have limited resources to meet the ever increasing and unlimited demand of the customers, marketers really have to think hard to utilize the resources (be it financial, human or product material). Successful green marketing entails much more than simply adding an environmental attribute into a product. According to the American Marketing Association, green marketing is the marketing of products that are presumed to be environmentally safe. Thus green marketing incorporates a broad range of activities, including product modification, changes to the production process, packaging changes, as well as modified advertising.

Green marketing like traditional marketing also works with 4P's of product, price, promotion and place. However, the difference lies in the way they are aligned to work. For example, planning of products is done so as to reduce consumption and environment pollution. Price is usually set keeping in mind that the product should portray improved performance, design , visual appeal or taste. Similarly, focusing on the promotional mix of green marketing which involves designing advertisements that address a positive and friendly relationship between the offered product or service and the biophysical environment or advertisements that promote a green lifestyle by highlighting a product or service and /or advertisements that present a corporate image of environmental responsibility. Place indicate where and when to make the product available for customers. Present paper focuses on the promotional mix of green marketing and tries to explore various impediments towards green media selection After recognizing the various criteria , it tries to study the interrelationships amongst them with the help of Interpretive Structural Modeling (ISM) methodology.

The paper is arranged as follows: Section II deals with the literature review. Section III describes the case problem and identifies various factors. Section IV describes the ISM methodology and its applications. Section V presents the managerial implications of using the methodology and extensions whereas section VI presents conclusions and future research directions.

\section{LITERATURE REVIEW}

There are various factors or criteria which influence the consumers' as well as marketers' perceptions about green marketing. Identification of these criteria has been made using keywords such as green marketing, green media, green media selection, sustainable marketing, sustainable products etc. to get relevant abstracts of research papers or full research papers based on the topic. Use of Mendeley software and Research Gate engine was an additional advantage. The resulting list of reference papers attempts to covers the last fifteen years period.

\subsection{Critical factors that impede the selection of green media}

Based on literature review, following factors are considered as impediments for green media selection from company's or advertiser's perspective:

\section{- Absence of use of documented green environmental policies (AEP) [10]}

Companies keen on committing to care for the green environment should consider using their green environmental policies in their decision making including media decisions for marketing communication purposes. 


\section{- Personal beliefs and / or Previous experience (PB/PE)}

Often marketing managers are driven by their personal beliefs while taking decisions about green environmental aspects in their working tasks. They have predisposed ideas on which media to use. If these aspects are considered mere as a trend than as a obligation , consumer's media attitudes and behavior towards green environment might get overlooked by managers and marketers thereby posing a competitive disadvantage .

\section{- Appointment of main agency (AMA)}

Appointment of a main agency can create a number of obstacles for selecting more effective media in general and green media in particular. For example, it may form a hierarchical structure in the agency network which acts as barrier which may block the other agencies from directly providing the marketing manager with updated information on advertising media as well as on current trends in media consumption, such as eco-harmful media perceptions.

\section{- Small firm size (SFS) [9]}

It has been found in the previous studies that firm size has positive effects on environmental performance [5,13]. Small firms cannot afford the cost of latest technology. International stores like Wall Mart and JC Penny, force the manufacturer for the consideration of environmental issues and the production of green products.

\section{- Position of firm (PF) [9]}

As per literature, position of firms in value chain is an important factor in influencing the environmental behavior . This is usually guided by top-level management's interest and support which is further considered as an essential factor for the green initiatives [6].

\section{- Strategic attitude (SA) [9]}

Competitiveness is an important motivation for firms to 'go green'[4]. According to Banerjee [2], different industry exhibit different motivation and actions in relation to environmental marketing .

\section{- Stakeholders pressure (SP)[9]}

Companies tend to act on the basis of pressure applied by their various stakeholders who are usually of two types [5]. These are primary stakeholders such as customers, suppliers and organization without whose support organization cannot generally survive and secondary or indirect stakeholders such as media, non-governmental organizations and social groups.

\section{- Cost and budgetary constraints (CBC) [10]}

Manufacturing of green products require huge investment in technology and R\&D and therefore funding for green marketing of these products become a more costlier phenomenon. It may require renewable and recyclable material, which is costly. Also, choice of media for green marketing of these products require funds.

\section{- Location (Lo) [10]}

Where the product is going to sell or the target market segment also play a very important role in determining the kind of green media to be used .

\section{ISM METHODOLOGY}

Interpretive Structural Modeling or ISM proposed by [5] presents the unique interrelated variables in the form of a structured hierarchy graph. Group or expert judgement decides whether and how the items are related.
Process of ISM follows the steps viz. identifying the relevant elements and first developing a structural self-interaction matrix (SSIM) using VAXO technique and then constructing an initial reachability matrix and then a final reachability matrix. After that level partition matrices are constructed based on establishing the precedence relationships and arranging the elements in topological order. Finally, a diagraph is created along with the driver-dependence diagram or MICMAC diagram in which the variables are classified in to the categories like autonomous, dependent, driver and linkage.

\section{DEVELOPMENT OF ISM MODEL}

In this section, ISM model is developed for analyzing the interrelationships between various factors affecting marketer's perception about green marketing and green media selection in India. Around 09 variables are considered important. They are Cost \& budget (CB), personal beliefs or previous experience ( $\mathrm{PB} / \mathrm{PE})$; appointment of main agency (AMA); small firm's size (SFS) ; position of firm (PF) ; strategic attitude (SA) ; stakeholder pressure (SP); absence of use of documented green environmental policies (AEP); and location (Lo) .

\subsection{Construction of Structural Self- Interaction Matrix (SSIM)}

This matrix gives the pair-wise relationship between two variables i.e. $i$ and $j$ based on VAXO.

Table I . Structural self - interaction matrix

\begin{tabular}{|c|c|c|c|c|c|c|c|c|c|c|}
\hline & & 1 & 2 & 3 & 4 & 5 & 6 & 7 & 8 & 9 \\
\hline & & CB & $\begin{array}{c}\text { P } \\
\text { B/ }\end{array}$ & $\begin{array}{c}\text { AM } \\
\text { A }\end{array}$ & SFS & PF & SA & S & AE & L \\
$\mathbf{~}$ & & & P & P \\
1. & CB & & A & V & A & A & X & A & V & A \\
\hline 2. & $\begin{array}{c}\text { PB } \\
\text { /PE }\end{array}$ & & & V & A & X & V & O & V & A \\
\hline 3. & AMA & & & & O & A & A & A & V & A \\
\hline 4. & SFS & & & & & A & V & A & V & A \\
\hline 5. & PF & & & & & & V & X & V & A \\
\hline 6. & SA & & & & & & & O & V & A \\
\hline 7. & SP & & & & & & & & X & A \\
\hline 8. & AEP & & & & & & & & & A \\
\hline 9. & Lo & & & & & & & & & \\
\hline
\end{tabular}

Explanation : Cost and budget to be allocated for media selection and green marketing could be drive by the manager's personal beliefs or past experiences . If he/she feels strongly about the environmental concerns, they might make strong appeals towards green marketing and consequently 
may ask for allotment of more budget towards green media . Personal beliefs or past experience will lead to strategic attitude, absence of documented environment policies and appointment of main agency. Similarly, position of firm in the value chain, size of firm, strategic attitude of the organization, location of the firm decides on the cost and budget to be allotted for green marketing . Appointment of agency is usually driven by location of firm, strategic attitude of the organization, position of firm, stakeholder's pressure . Appointment of main agency may lead to absence of environment policies .

\subsection{Construction of Initial Reachability Matrix}

The SSIM has been converted in to a binary matrix, called the initial reachability matrix by substituting $\mathrm{V}, \mathrm{A}, \mathrm{X}, \mathrm{O}$ by 1 or 0 as per the case

Table II. Initial Reachability Matrix

\begin{tabular}{|c|c|c|c|c|c|c|c|c|c|c|}
\hline & & 1 & 2 & 3 & 4 & 5 & 6 & 7 & 8 & 9 \\
\hline & & $\begin{array}{l}\text { C } \\
\text { B }\end{array}$ & $\begin{array}{c}\mathbf{P B} \\
/ \mathbf{P} \\
\mathrm{E}\end{array}$ & $\begin{array}{c}\mathbf{A M} \\
\mathbf{A}\end{array}$ & $\begin{array}{c}\text { SF } \\
\text { S }\end{array}$ & $\begin{array}{l}\mathbf{P} \\
\mathbf{F}\end{array}$ & $\begin{array}{l}\text { S } \\
\text { A }\end{array}$ & $\begin{array}{l}\mathbf{S} \\
\mathbf{P}\end{array}$ & $\begin{array}{c}\mathbf{A E} \\
\mathbf{P}\end{array}$ & $\begin{array}{l}\mathbf{L} \\
\mathbf{0}\end{array}$ \\
\hline 1. & CB & 1 & 0 & 1 & 0 & 0 & 1 & 0 & 0 & 0 \\
\hline 2. & $\begin{array}{l}\mathbf{P B} \\
/ \mathbf{P E}\end{array}$ & 1 & 1 & 1 & 0 & 1 & 1 & 0 & 1 & 0 \\
\hline 3. & $\underset{\mathbf{A}}{\mathbf{A M}}$ & 0 & 0 & 1 & 0 & 0 & 0 & 0 & 1 & 0 \\
\hline 4. & SFS & 1 & 1 & 0 & 1 & 0 & 1 & 0 & 1 & 0 \\
\hline 5. & $\mathbf{P F}$ & 1 & 1 & 1 & 1 & 1 & 1 & 1 & 1 & 0 \\
\hline 6. & $\mathbf{S A}$ & 1 & 0 & 1 & 0 & 0 & 1 & 0 & 1 & 0 \\
\hline 7. & SP & 1 & 0 & 1 & 1 & 1 & 0 & 1 & 1 & 0 \\
\hline 8. & $\begin{array}{c}\mathbf{A E} \\
\mathbf{P}\end{array}$ & 0 & 0 & 0 & 0 & 0 & 0 & 0 & 1 & 0 \\
\hline 9. & Lo & 1 & 1 & 1 & 1 & 1 & 1 & 1 & 1 & 1 \\
\hline
\end{tabular}

\subsection{Construction of final reachability matrix}

This requires looking for transitivity and correcting it. There are some transitive relationships and they are updated in the final reachability matrix. These transitivity relationships have been incorporated to obtain the final reachability matrix as follows:

Table III. Final reachability matrix

\begin{tabular}{|c|c|c|c|c|c|c|c|c|c|c|}
\hline & 1 & 2 & 3 & 4 & 5 & 6 & 7 & 8 & 9 & \\
\hline & $\mathbf{C}$ & $\mathbf{P}$ & $\mathbf{A}$ & $\mathbf{S}$ & $\mathbf{P}$ & $\mathbf{S}$ & $\mathbf{S}$ & $\mathbf{A}$ & $\mathbf{L}$ & $\mathbf{D . P}$ \\
& $\mathbf{B}$ & $\mathbf{B}$ & $\mathbf{M}$ & $\mathbf{F}$ & $\mathbf{F}$ & $\mathbf{A}$ & $\mathbf{P}$ & $\mathbf{E}$ & $\mathbf{0}$ & \\
\hline $\mathbf{P}$ & $\mathbf{A}$ & $\mathbf{S}$ & & & & $\mathbf{P}$ & & \\
\hline $\mathbf{C B}$ & 1 & 0 & 1 & 0 & 0 & 1 & 0 & 1 & 0 & 4 \\
\hline $\begin{array}{c}\mathbf{P B} / \mathbf{P} \\
\mathbf{E}\end{array}$ & 1 & 1 & 1 & 0 & 1 & 1 & 0 & 1 & 0 & 6 \\
\hline $\begin{array}{c}\mathbf{A M} \\
\mathbf{A}\end{array}$ & 1 & 0 & 1 & 0 & 0 & 0 & 0 & 1 & 0 & 3 \\
\hline
\end{tabular}

\begin{tabular}{|c|c|c|c|c|c|c|c|c|c|c|}
\hline SFS & 1 & 1 & 1 & 1 & 1 & 1 & 0 & 1 & 0 & 7 \\
\hline PF & 1 & 1 & 1 & 1 & 1 & 1 & 1 & 1 & 0 & 8 \\
\hline SA & 1 & 0 & 1 & 0 & 0 & 1 & 1 & 1 & 0 & 5 \\
\hline SP & 1 & 1 & 1 & 1 & 1 & 1 & 1 & 1 & 0 & 8 \\
\hline AEP & 1 & 0 & 1 & 0 & 0 & 0 & 0 & 1 & 0 & 3 \\
\hline Lo & 1 & 1 & 1 & 1 & 1 & 1 & 1 & 1 & 1 & 9 \\
\hline De.P & 9 & 5 & 9 & 4 & 5 & 7 & 4 & 9 & 1 & \\
\hline
\end{tabular}

\subsection{Level Partition}

From the final reachability matrix, the reachability and final antecedent set for each factor are found. For the top level element, the reachability and intersection sets are the same. After identification, top level element is separated out from the other elements to continue the process to find the next level of elements. Various iterations have been shown in Table IV -Table IX below.

Table IV. Iteration 1

\begin{tabular}{|c|c|c|c|}
\hline $\begin{array}{c}\text { Reachability } \\
\text { set }\end{array}$ & $\begin{array}{c}\text { Antecedent } \\
\text { set }\end{array}$ & $\begin{array}{c}\text { Intersection } \\
\text { set }\end{array}$ & Level \\
\hline 3 & $1,2,3,4,5,6,7,8,9$ & 3 & \multirow{2}{*}{ I } \\
\hline 3,8 & $1,2,3,4,5,6,7,8,9$ & 3,8 & \\
\hline $\mathbf{1 , 3 , 8}$ & $1,2,3,4,5,6,7,8,9$ & $\mathbf{1 , 3 , 8}$ & \\
\hline $1,3,5,6,8$ & $2,4,5,6,7,9$ & 5,6 & \\
\hline $1,2,3,5,8$ & $2,4,5,7,9$ & 2,5 & \\
\hline 1,6 & $1,2,4,5,6,7,9$ & 1.6 & \\
\hline $2,4,5,7,8$ & $5,7,9$ & 5,7 & \\
\hline $1,2,3,4,5,6,7,8,9$ & 9 & 9 & \\
\hline $1,2,3,4,5,6,7,8$ & $4,5,7,9$ & $4,5,7$ \\
\hline
\end{tabular}

Table V. Iteration 2

\begin{tabular}{|c|c|c|c|}
\hline $\begin{array}{c}\text { Reachability } \\
\text { set }\end{array}$ & $\begin{array}{c}\text { Antecedent } \\
\text { set }\end{array}$ & $\begin{array}{c}\text { Intersection } \\
\text { set }\end{array}$ & Level \\
\hline 5,6 & $2,4,5,6,7,9$ & 5,6 & \\
\hline 2,5 & $2,4,5,7,9$ & 2,5 & \\
\hline $\mathbf{6}$ & $2,4,5,6,7,9$ & $\mathbf{6}$ & \multirow{2}{*}{ II } \\
\hline $2,4,5,7$ & $5,7,9$ & 5,7 & \\
\hline $2,4,5,6,7,9$ & 9 & 9 & \\
\hline $2,4,5,6,7$ & $4,5,7,9$ & $4,5,7$ & \\
\hline
\end{tabular}

Table VI. Iteration 3

\begin{tabular}{|c|c|c|c|}
\hline $\begin{array}{c}\text { Reachability } \\
\text { set }\end{array}$ & $\begin{array}{c}\text { Antecedent } \\
\text { set }\end{array}$ & $\begin{array}{c}\text { Intersection } \\
\text { set }\end{array}$ & Level \\
\hline $\mathbf{5}$ & $2,4,5,7,9$ & $\mathbf{5}$ & \\
\hline 2,5 & $2,4,5,7,9$ & 2,5 & \multirow{2}{*}{ III } \\
\hline $2,4,5,7$ & $5,7,9$ & 5,7 & \\
\hline $2,4,5,7,9$ & 9 & 9 & \\
\cline { 1 - 3 } $2,4,5,7$ & $4,5,7,9$ & $4,5,7$ & \\
\hline
\end{tabular}


Table VII. Iteration 4

\begin{tabular}{|c|c|c|c|}
\hline $\begin{array}{c}\text { Reachability } \\
\text { set }\end{array}$ & $\begin{array}{c}\text { Antecedent } \\
\text { set }\end{array}$ & $\begin{array}{c}\text { Intersection } \\
\text { set }\end{array}$ & Level \\
\hline $\mathbf{2}$ & $2,4,7,9$ & $\mathbf{2}$ & \multirow{2}{*}{ IV } \\
\hline $2,4,7$ & 7,9 & 7 & \\
\cline { 2 - 3 } $2,4,7,9$ & 9 & 9 & \\
\hline $2,4,7$ & $4,7,9$ & 4,7 & \\
\hline
\end{tabular}

Table VIII. Iteration 5

\begin{tabular}{|c|c|c|c|}
\hline $\begin{array}{c}\text { Reachability } \\
\text { set }\end{array}$ & $\begin{array}{c}\text { Antecedent } \\
\text { set }\end{array}$ & $\begin{array}{c}\text { Intersection } \\
\text { set }\end{array}$ & Level \\
\hline 4,7 & 7,9 & 7 & \multirow{2}{*}{ V } \\
\cline { 1 - 3 } $4,7,9$ & 9 & 9 & \\
\cline { 1 - 3 } $\mathbf{4 , 7}$ & $4,7,9$ & $\mathbf{4 , 7}$ & \\
\hline
\end{tabular}

Table IX. Iteration 6

\begin{tabular}{|c|c|c|c|}
\hline $\begin{array}{c}\text { Reachability } \\
\text { set }\end{array}$ & $\begin{array}{c}\text { Antecedent } \\
\text { set }\end{array}$ & $\begin{array}{c}\text { Intersection } \\
\text { set }\end{array}$ & Level \\
\hline 9 & 9 & 9 & VI \\
\hline
\end{tabular}

\subsection{Classification of factors}

In this section, a MICMAC analysis of factors affecting consumer perception about green media selection is made. As it can be seen that there is no autonomous criteria. Criteria such as CB, AEP and AMA are dependent criteria. They have high dependence and low to medium driving power. Similarly, Lo, SP, PF, PB/PE have low dependence but high driving power and hence they are drivers whereas SA and SFS can be considered as a linkage criteria which falls for high driving as well as dependence power.

Table X . Driving Power \& Dominance Diagram

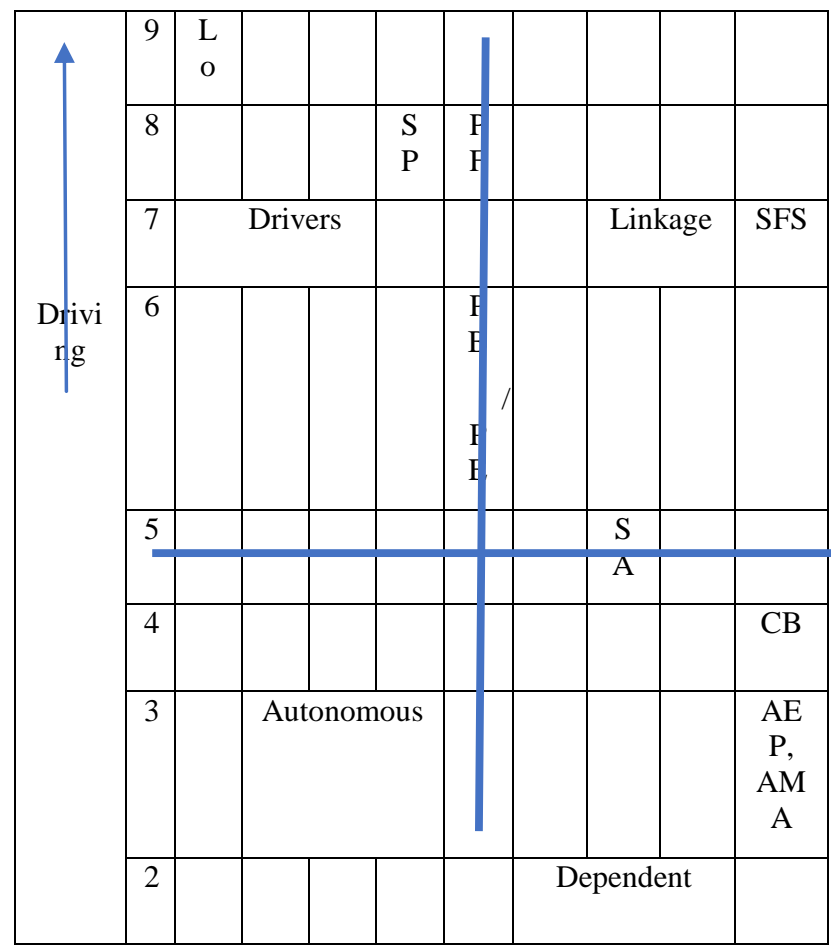

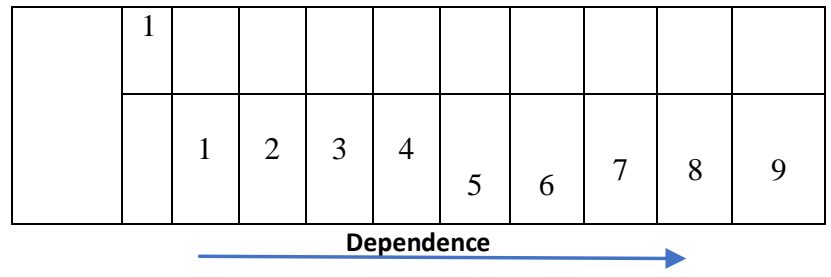

\subsection{ISM-The Diagraph}

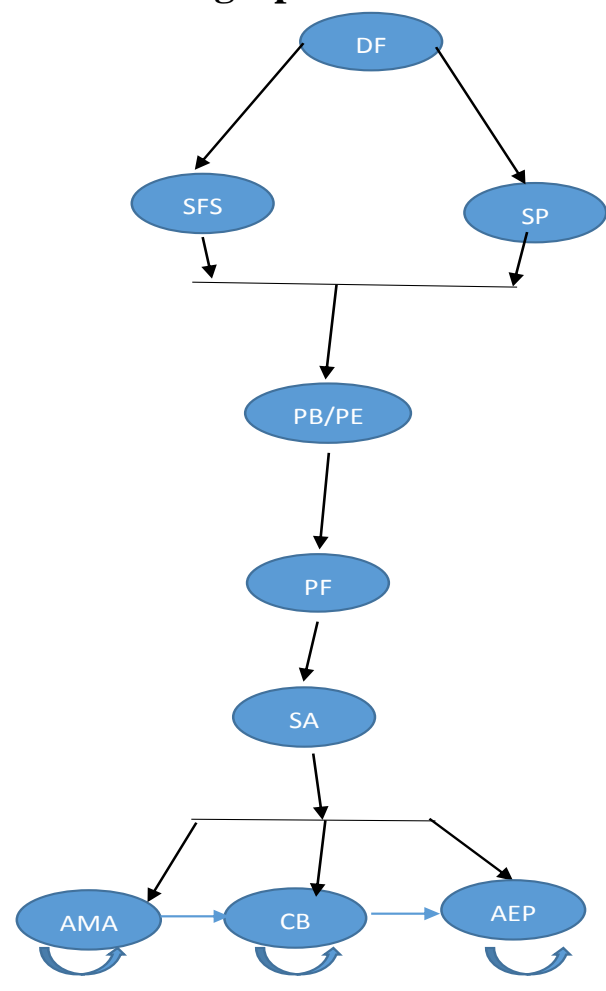

\section{MANAGERIAL IMPLICATIONS}

The study of dependency relationships between various criteria affecting manufacturers' and marketers' perception about green media selection and subsequently its adoption with the help of ISM methodology would benefit academicians and research scholars as this study gives further insights in this field and there are less numbers of researches available especially in Indian context.

\section{CONCLUSIONS}

Present research work focuses on suggesting an ISM methodology for studying the interrelationship between various criteria affecting the consumer perception about green media selection. This topic is quite new and emerging from Indian perspective as consumers are getting environment conscious. The research topic can further be extended to include hybrid methodologies such as fuzzy DEMATEL or TOPSIS.

\section{REFERENCES}

[1] Rademaker, C.A. 2013. Green media : Exploring Green Media Selection and its impact on communication effectiveness. Doctoral thesis submitted to Department of Marketing and Strategy at the Stockholm School of Economics (SSE), ISBN 978-91-7258-878-3.

[2] Hunter, C.B. and E.R. Auster, E.R.1990. Proactive environmental management: avoiding the toxic trap. Slogan Management Review, 31(2), 7-18.

[3] Clarkson 1995. A stake holder framework for analyzing 
and evaluating corporate social performance. Academy of Management Review, 29(I), 92-117.

[4] Gonzalez-Benito, J. and Gonzalez-Benito, O. 2006. A .review of determinant factors of environmental productivity. Business Strategy and the environment, $15,87-102$.

[5] Warfield, J.N. 1974. Developing interconnection matrices in structural modeling", in the proceedings of IEEE Transactions on System, Man, and Cybernetics, SMC, 4 (1),81-87.

[6] Siddique, M. ,Hayat, K. and Cheema, K.U.R 2014. Impediments of green marketing in Pakistan. http://mpra.ub.uni-muenchen.de/53196/

[7] Bansal, P. and Roth, K. 2000. Why companies go green: a model of ecological responsiveness, Academy of Management Journal, 43 (4), 717-736.

[8] Melnyk, S.A. Sroufe, R.P. and Calantone, R. 2003. Assessing the impact of environmental management systems on corporate and environmental performance. Journal of Operations Management, 21(3), 329-351.

[9] Banerjee, S.B. 2001. Managerial perceptions of corporate environmentalism: interpretations form industry and strategic implications for organizations. Journal of Management Studies, 38(4), 489-513.

[10] William, Y., Kumju, H. and Caroline, J.O. 2010 Sustainable Consumption: Green Consumer Behaviour when Purchasing Products, Sustainable development, 18, 20-31, Wiley online library. 